\title{
Birden Fazla Boşluklu Çift Doğrultulu Betonarme Döşemelerin Zımbalama Performansının İyileştirilmesi için Tekstil ile Güçlendirilmiş Sıva Şeritler ile Güçlendirilmesi
}

\author{
Improving Punching Behavior of RC Two Way Slab with Multiple Openings \\ Strengthened by using Textile Reinforced Mortar Strip
}

\author{
Ömer Mercimek $^{1 *}$ (D), Rahim Ghoroubi ${ }^{\text {iD }}$ Özgür Anıl ${ }^{\text {(iD }}$ Mehmet Baran $^{4}$ iD \\ ${ }^{I}$ Araştırma Görevlisi, Ankara Yıldırım Beyazı Üniversitesi Mühendislik Fakültesi, İnşaat Mühendisliği Bölümü, 06010, Ankara, TÜRKIYYE \\ ${ }^{2}$ Öğretim Görevlisi Dr., Çankaya Üniversitesi,Mühendislik Fakültesi, İnşaat Mühendisliği Bölümü, 06790, Ankara, TÜRKIYYE \\ ${ }^{3}$ Prof. Dr., Gazi Üniversitesi, Mühendislik Fakültesi, İnşaat Mühendisliği Bölümü, 06570, Ankara, TÜRKIYYE \\ ${ }^{4}$ Doç.Dr., Ankara Yıldırım Beyazıt Üniversitesi, Mühendislik Fakültesi, İnşaat Mühendisliği Bölümü, 06010, Ankara, TÜRKIYE
}

Başvuru/Received: 02/03/2021

Kabul / Accepted: 11/04/2021

Çevrimiçi Basım / Published Online: 23/05/2021

Son Versiyon/Final Version: 18/06/2021

\begin{abstract}
$\ddot{O} z$
Betonarme kirişsiz döşemelerde meydana gelebilecek olan ani ve gevrek bir şekilde, hiçbir deformasyon belirtisi göstermeden oluşan zımbalama göçme mekanizması yapı içerisinde yaşayanlara zarar verebilecek son derece tehlikeli bir göçme şeklidir. Bu nedenle tasarım aşamasında kaçınılan göçme mekanizmalarının başında gelmektedir. Betonarme döşemelerde farklı nedenlerden dolayı bırakılan boşlukların, döşemelerin zımbalama dayanımını ve davranışını olumsuz etkilediği bilinmektedir. Bu nedenle betonarme çift doğrultulu döşemelerde birden fazla boşluğun döşemelerin zımbalama davranışı üzerindeki olumsuz etkilerinin belirlenmesi ve boşlukların meydana getirdiği davranış problemlerinin azaltılabilmesi için tekstil ile takviye edilmiş sıva şeritler ile döşemelerin güçlendirilmesinin incelendiği deneysel bir çalışma planlanmıştır. Bu çalışma kapsamında biri boşluksuz referans elemanı, 4 deney elemanı ise $300 \times 300 \mathrm{~mm}$ boyutlarında kare kesitli iki adet boşluklu olacak şekilde toplamda 5 döşeme deney elemanı üretilmiştir. Boşluklu deney elemanlarının ikisi tekstil ile güçlendirilmiş sıva katmanlı (TGSK) şeritler ile güçlendirilerek deney elemanlarının zımbalama davranışı üzerinde boşlukların meydana getirdiği olumsuz etkilerin ne ölçüde iyileştirilebildiği deneysel olarak araştıılmıştır. Deney elemanlarının güçlendirilmesi sırasında çift doğrultulu karbon tekstil (hasır şeklinde) kullanılmıştır. Çalışma kapsamında TGSK şeritler ile geliştirilen ve uygulanan güçlendirme metodunun döşemelerin zımbalama dayanımını önemli ölçüde artırdığı, boşlukların meydana getirdiği olumsuz etkileri sınırlandırdığı görülmüştür.
\end{abstract}

\section{Anahtar Kelimeler}

"Çift doğrultulu betonarme döșeme, Birden fazla boşluk, Zımbalama, Tekstil ile güçlendirilmişs sıva"

\begin{abstract}
The punching collapse mechanism, which can occur in slabs without reinforced concrete beams in a sudden and brittle way, without showing any signs of deformation, is an extremely dangerous form of collapse that can harm the inhabitants of the building. For this reason, it is one of the most avoided failure mechanisms during the design phase. It is known that the openings left in reinforced concrete slabs, negatively affect the punching strength and behavior of the slabs. For this reason, an experimental study was planned to determine the negative effects of more than one opening on the punching behavior of the reinforced concrete two-way slabs and to reduce the problems caused by the openings, examining the strengthening of the slabs with textile reinforced mortar strips. Within the scope of this study, a total of 5 slab test specimens were produced, one of which is a reference specimen without opening and four of them are 300x300 $\mathrm{mm}$ opening with square cross-section. To what extent the negative effects caused by the openings on the punching behavior of the test specimens could be improved by strengthening two of the opening test specimens with textile reinforced mortar strip (TRM) was investigated experimentally. During the strengthening of the specimens, bidirectional carbon textile was used. Within the scope of the study, it was observed that the strengthening method developed and applied with TRM strips significantly increased the punching strength of the slabs and limited the negative effects caused by the openings.
\end{abstract}

Key Words

"Two way RC slab, Multiple opening, Punching, Textile reinforced mortar" 


\section{Giriş}

Deprem tehlikesinin yüksek olduğu coğrafyalarda deprem performansı düşük çok sayıdaki yapının güçlendirilmesi gerekliliği, söz konusu yapıların kısa sürede, içeride yaşayan insanları minimum düzeyde rahatsız ederek, düşük maliyetli ve çok yüksek düzeyde uzmanlık gerektirmeyecek bir işçilik ile güçlendirilme çalışmalarının yapılması ihtiyacını da ortaya çıkarmıştır. Yürütülen çalışmalar bu özellikleri taşıyan güçlendirme detaylarının geliştirilmesi üzerine yoğunlaşmış ve çok daha kısa sürede, basit bir şekilde kolay uygulanabilecek ve ekonomik malzemelerin kullanıldığı güçlendirme detaylarının geliştirilmesi konusundaki araştırmalar artış göstermiştir. Son 20 yıldır lif takviyeli polimer (FRP) ile güçlendirme yaygın bir şekilde kullanılmış ve birçok yapı bu teknik ile güçlendirilmiştir. Ayrıca, konu ile ilgili birçok bilimsel çalışma yapılmış ve güçlendirme-onarım çalışmalarında FRP en çok tercih edilen malzemelerden biri haline gelmiştir (Gemi ve diğerleri, 2019, 2020; Aksoylu ve diğerleri, 2020; Mercimek ve diğerleri, 2020, 2021; Özkılıç ve diğerleri, 2021; Ghoroub1 ve diğerleri, 2020, 2021; İşleyen ve diğerleri, 2021). Buna rağmen, tekstil ile güçlendirilmiş çimento esaslı malzemelerin yapısal güçlendirme alanında kullanımı son 10 yıl içerisinde artış göstererek yapı sistemi ve elemanlarının güçlendirme ve onarım çalışmalarında bu tür malzemeler de kullanılmaya başlanmıştır. Tekstil örgü ağların sıva katmanı arasında bir güçlendirme detayı olarak kullanılması diğer kompozit malzemelerin özel yapıştırıcılar ile güçlendirme amacıyla kullanılmasına göre çok daha ekonomik olması, çevre dostu bir seçenek olması, taşıyıcı özelliğinin yüksekliği gibi nedenlerden tercih edilen bir seçenek haline gelmiştir. Bu nedenle çalışması kapsamında tekstil ile güçlendirilmiş sıva katmanı (TGSK) eklenmesi tekniğinin birden fazla boşluklu betonarme döşemelerin zımbalama davranışının iyileştirilmesinde kullanılması amaçlanmıştır.

TGSK ile güçlendirme yöntemi betonarme döşemelere de uygulanmış ve olumlu sonuçlar alınmış olduğu yapılan literatür taraması sonucunda görülmüştür. Ancak betonarme döşemelerin TGSK ile güçlendirilmesine ait çalışmaların sayısı yığma yapı elemanlarına, betonarme kiriş ve kolonlara kıyasla çok daha azdır. Jesse ve diğerleri (2008) ve Papanicolaou ve diğerleri (2009) tarafından yürütülen çalışmalar bu konudaki ilk çalışmalardır. Bu çalışmaların devamında Schladitz ve diğerleri (2012) tarafından yürütülen deneysel ve teorik çalışmada TGSK (karbon bazlı) ile güçlendirilmiş tek doğrultulu betonarme döşemelerin eğilme taşıma kapasiteleri araştırılmıştır. Schladitz ve diğerlerinin (2012) çalışmasına benzer bir çalışma da Zwicky (2013) tarafından gerçekleştirilmiştir. Zwicky, diğer çalışmalardan farklı olarak tekstil üzerine uygulanan harcı basınçlı bir şekilde püskürterek uygulamış ve bağlanmayı arttırmaya çalışmıştır. Bir başka çalışmada, Giovanni ve diğerleri (2014) yine TGSK ile güçlendirilen betonarme döşemelerin performansını değerlendirmişlerdir. Jung ve diğerleri (2016) yine tek doğrultulu ve karbon bazlı TGSK ile güçlendirilmiş betonarme döşeme elemanlarında eğilme etkisini incelemiş ancak diğer çalışmalardan farklı olarak güçlendirme uygulaması sırasında ankraj sistemi de kullanmışlardır. Uygulanan ankraj sistemiyle süneklikte de artışlar olduğu gözlemlenmiştir. Betonarme döşemelerin TGSK ile güçlendirilmesi konusunda literatürde yer alan çalışmaların neredeyse tamamında tek doğrultulu betonarme döşeme kullanılmıştır. Çift doğrultulu döşemelerle ilgili çalışmalar oldukça kısıtlıdır. Literatür incelendiğinde konu ile ilgili Papanicolaou ve diğerleri (2009) ve Koutas ve Bournas (2017) tarafından yürütülen iki çalışma karşımıza çıkmaktadır. Papanicolaou ve diğerleri (2009) 4 adet kare betonarme döşemeden 3 adedini karbon ya da cam TGSK ile güçlendirmiş ve zımbalama etkisi oluşturmak için döşeme ortasında konsantre yük uygulayarak bu elemanları test etmişlerdir. Sonuç olarak, TGSK'nin zımbalama dayanım kapasitesinin artışında etkili olduğu gözlemlenmiştir. Diğer çalışmada ise Koutas ve Bournas (2017) 1.80 m kenar uzunluğuna sahip 6 adet kare betonarme döşeme elemanı üretmişler, bunlardan biri referans eleman olarak seçmişler ve dört noktada dağılmış monotonik yükleme altında test etmişlerdir. Değişkenler olarak ise, TGSK'nın cinsi (bazalt ya da cam), TGSK tabaka sayısı ve hasar oranı olarak seçilmiştir. Deneylerin sonucunda TGSK'nın uygulanma şekline de bağlı olarak çift doğrultulu döşemelerde taşıma kapasitesine olumlu katkılar da bulunduğu gözlemlenmiştir. TGSK ile güçlendirme konusunda yapılan çalışmalar genel olarak ele alındığında en az sayıdaki çalışmanın çift doğrultulu betonarme döşemelerde olduğu anlaşılmaktadır. Bununla birlikte pratikte çoğu kez zorunlu sebeplerden dolayı (asma kat, baca ve tesisat) döşemelerde boşluklar bırakılmakta ve bu döşemelerde zımbalama etkisi oldukça kritik bir durum haline gelmektedir. Boşluklu betonarme döşemelerin zımbalama dayanımının artırılması için TGSK ile güçlendirilmesi konusunda herhangi bir çalışmaya rastlanmamış, araştırılmaya açık ve uygulamalar düşünüldüğü zaman oldukça önemli bir konu olduğu düşünülmektedir. Yapılan literatür taraması ve incelemeler sonucunda birden fazla boşluğa sahip çift doğrultulu betonarme döşemelerin zımbalama yüklemesi etkisi altındaki davranışlarının incelendiği ve boşlukların döşemelerin zımbalama performansı üzerinde meydana getirdiği olumsuz etkilerin azaltılması için güçlendirme literatürüne yeni yeni girmeye başlayan TGSK şeritler ile boşluklu döşemelerin güçlendirilmesine yönelik deneysel bir çalışma yapılması planlanmıştır. Deneysel programda incelenen değişkenler betonarme döşemede yer alan boşlukların konumudur. Biri boşluksuz referans deney elemanı olmak üzere toplamda 5 adet betonarme deney elemanı üretilmiş ve zımbalama yüklemesi etkisi altında test edilerek döşemelerin yük-deplasman davranışları, maksimum taşıma güçleri, başlangıç rijitlikleri ve enerji tüketim kapasitesi değerleri elde edilerek yorumlanmıştır.

\section{Deneysel Çalışma}

Deneysel programda çift doğrultulu döşemelerde yer alan birden fazla boşluğun konumunun zımbalama dayanımı üzerindeki etkilerinin ve döşemelerdeki boşluğun zımbalama davranışı üzerinde meydana getirdiği olumsuz etkilerin azaltılması için TGSK şeritler ile uygulanan güçlendirme tekniğinin performansa etkilerinin incelenmesi hedeflenmiştir. Bu amaca yönelik olarak beş adet çift doğrultulu betonarme döşeme deney elemanı üretilmiş ve basit mesnetli olacak şekilde test edilmiştir. Deney elemanları $2000 \times 2000 \times 120 \mathrm{~mm}$ boyutlarında kirişsiz çift doğrultulu betonarme döşeme olarak tasarlanmış olup, deney elemanlarının donatı şeması Şekil 1'de verilmiştir. Deneysel programda yer alan deney elemanlarının özellikleri Tablo 1'de sunulmuştur. Deneysel programda yer alan birinci deney elemanı boşluksuz ve güçlendirme uygulanmayan referans deney elemanıdır. Deney elemanı 2 ve 3 'te ise $300 \times 300 \mathrm{~mm}$ kare geometriye sahip iki adet boşluk iki farklı konumda bırakılmış ve deney elemanları üzerinde boşlukların meydana getirdiği olumsuz etkilerin yorumlanabilmesi için güçlendirilmeden test edilmiştir. Deney elemanı 2'de yer alan boşluklar zımbalama yüklemesinin uygulandığı kolona göre kolona bitişik şekilde kolonun hemen üstünde ve altında paralel 
olarak konumlandırılmıştır. Deney elemanı 3 'te ise boşluklar döşeme kolonunun köşe noktalarına bitişik şekilde diyagonal şekilde yerleştirilmiştir. Deneysel programda yer alan 4. ve 5. deney elemanlarında ise boşlukların olumsuz etkilerinin azaltılması için TGSK şeritler ile döşemelere güçlendirme uygulanmıştır. Döşemelerin beton dökümü, hazır beton kullanılarak aynı anda tek grup halinde yapılmıştır. Döşemelerin test edildiği gün $150 \times 150 \times 150 \mathrm{~mm}$ boyutlarındaki küplerden ölçülen ortalama basınç dayanımı (beş numuneden alınan ortalama değerler) standart silindir numune $(150 \times 300 \mathrm{~mm})$ dayanımına çevrilerek Tablo 1'de her deney elemanı için verilmiştir. Kolon boyuna donatısı ve döşemelerde çekme ve basınç donatısı olarak kullanılan 10 mm çapındaki nervürlü donatıların akma dayanımı $480 \mathrm{MPa}$, çekme dayanımı $627 \mathrm{MPa}$ ve elastisite modülü ise 195 GPa'dır. Kolon etriyelerinde kullanılan $4 \mathrm{~mm}$ çapındaki düz donatı için bu değerler $280 \mathrm{MPa}, 427 \mathrm{MPa}$ and $193 \mathrm{GPa}$ 'ır. Bu değerler beş numuneden elde edilen ortalama değerlerdir. Tüm döşemeler eğilmeye karşı yüksek dayanıma sahip olacak şekilde donatılandırılmıştır.
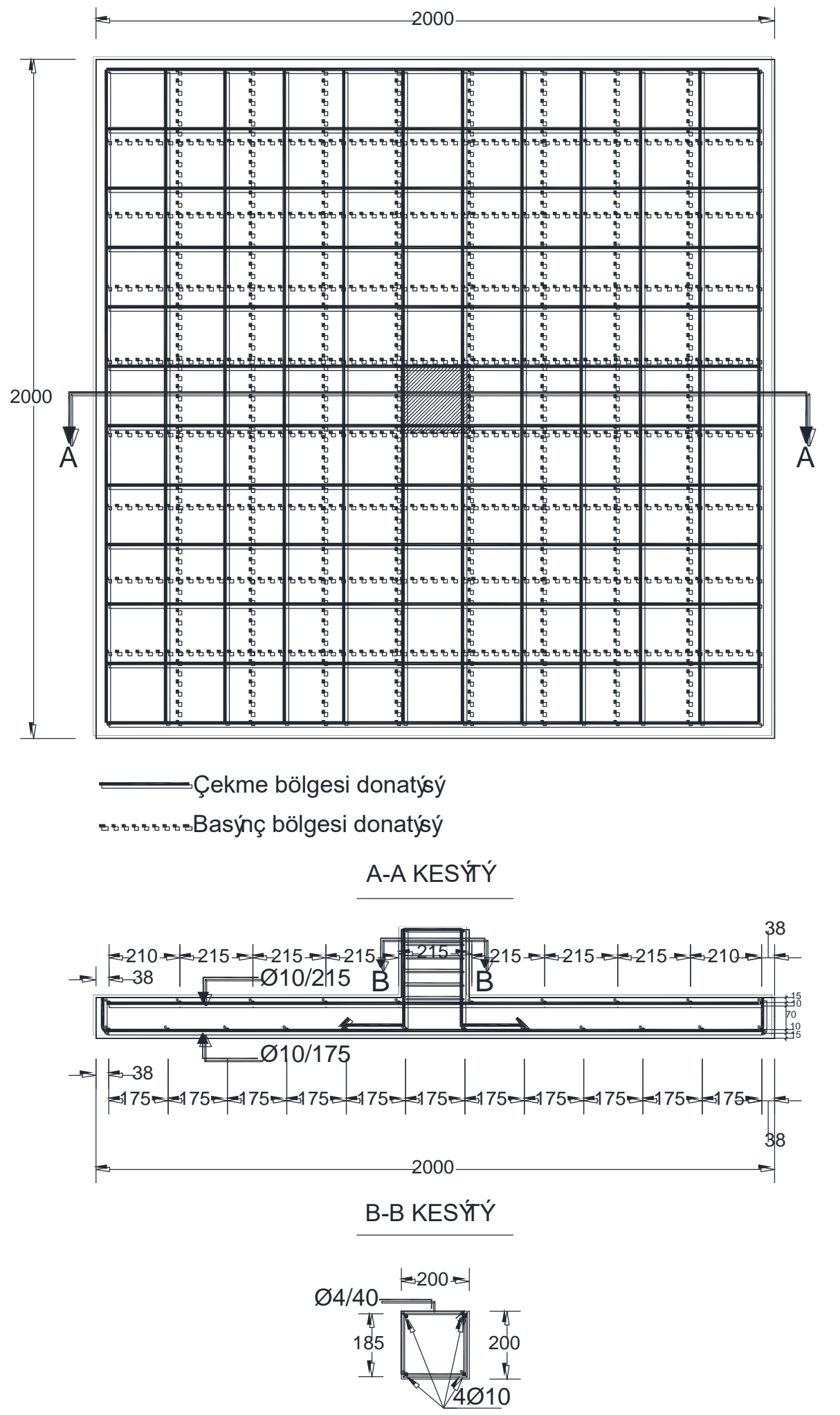

Şekil 1. Deney elemanlarının geometrik boyutları ve donatı detayı (Tüm ölçüler mm'dir.) 
Tablo 1. Deney elemanlarının özellikleri

\begin{tabular}{lllll}
\hline $\begin{array}{l}\text { Deney El. } \\
\text { No }\end{array}$ & $\begin{array}{l}\text { Uygulama } \\
\text { Türü }\end{array}$ & $\begin{array}{l}\text { Beton Basınç } \\
\text { Dayanımı fC }(\mathrm{MPa})\end{array}$ & $\begin{array}{l}\text { Boşluk } \\
\text { Büyüklüğü } \\
(\mathrm{mm})\end{array}$ & Boşluğun Konumu \\
\hline 1 & Güçlendirmesiz & 25,6 & \multicolumn{2}{c}{ Boşluksuz referans deney elemanı } \\
2 & & 25,2 & $300 \times 300$ & $\begin{array}{l}\text { Kolona göre paralel alt ve üstte } \\
\text { Kolona göre diyagonal köşelerde }\end{array}$ \\
4 & & 25,4 & $300 \times 300$ & $\begin{array}{l}\text { Kolona göre paralel alt ve üstte } \\
\text { Kolona göre diyagonal köşelerde }\end{array}$ \\
\hline
\end{tabular}

10 mm çapa sahip nervürlü donatılar döşemenin üst tarafında her iki yönde $215 \mathrm{~mm}$ aralıklarla, alt tarafında yine her iki yönde 175 $\mathrm{mm}$ aralıklarla yerleştirilmiştir. Döşemenin alt tarafında bulunan tüm nervürlü donatıların uç kısımları 90 yukarı yönlü eğilerek ankrajlama sağlanmıştır. Bunların yanı sıra, gerçek bir binada bulunan döşemede açılan boşluğu en iyi şekilde temsil edebilmek için basınç ve çekme donatıları boşlukların denk geldiği bölümlerde kesilmiş ve boşluk kenarlarında ayrıca özel bir donatılandırma detayı uygulanmamıştır. Deneysel çalışma kapsamında döşemelerde bırakılan boşlukların büyüklükleri ve konumları Şekil 2'de verilmiştir.

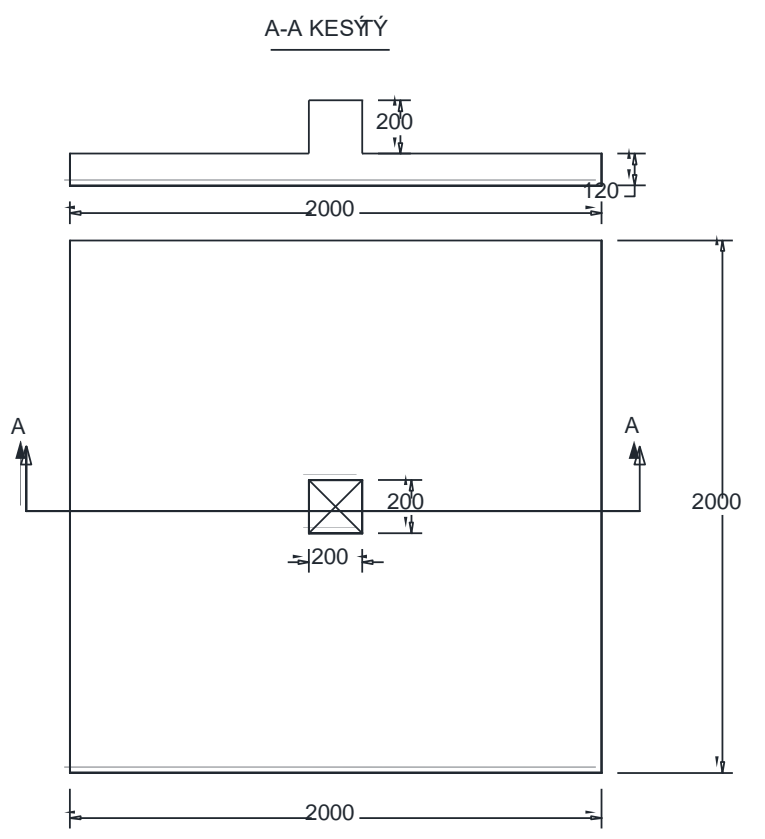

Deney Eleman1-1

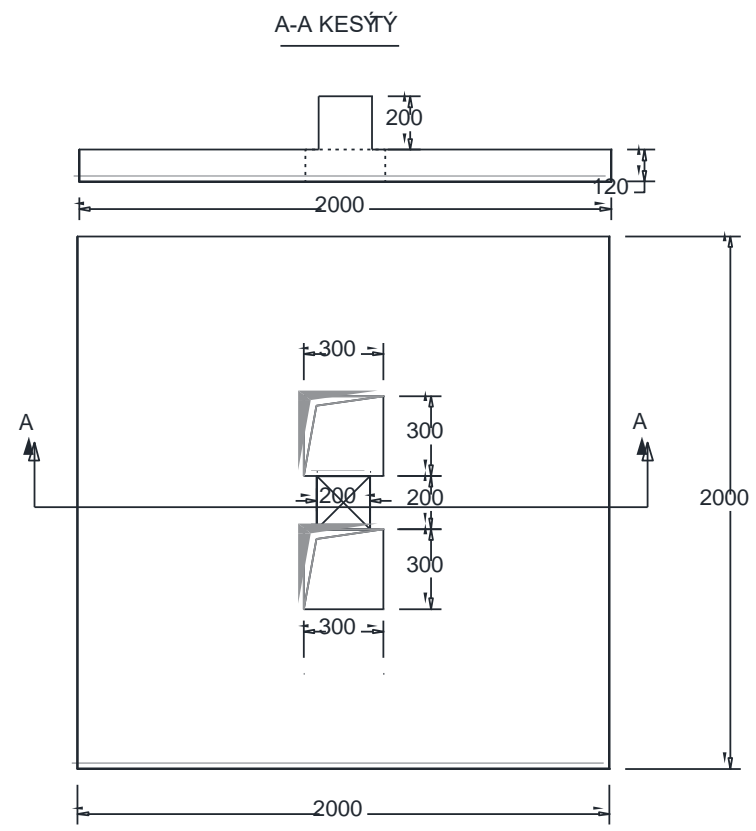

Deney Eleman1-2 ve 4

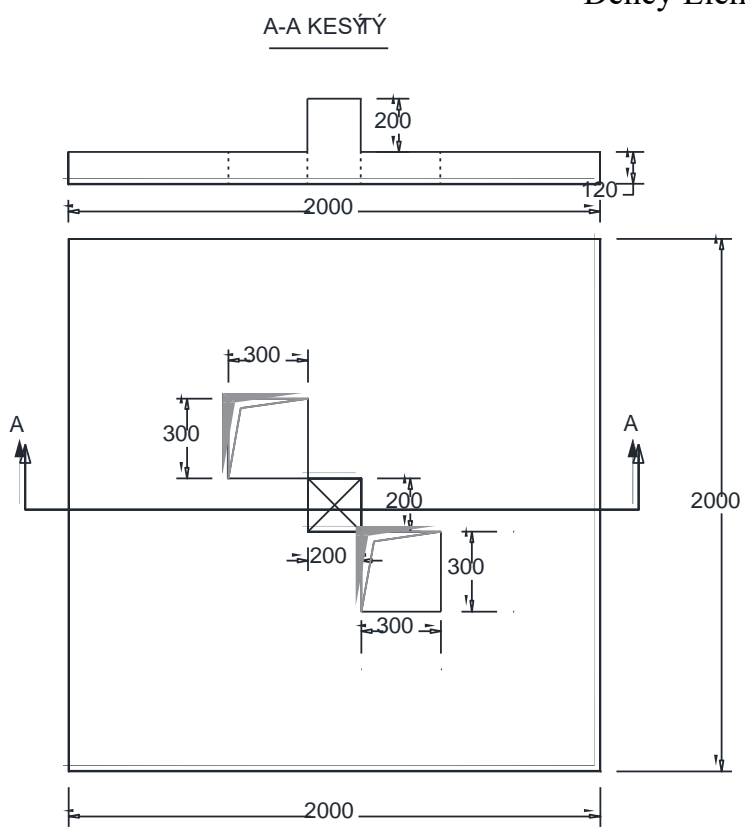

Deney Elemanı-3 ve 5

Şekil 2. Deney elemanlarında bırakılan boşlukların konumları (Tüm ölçüler mm’dir.) 
Deneysel programda yer alan Deney elemanı-4 ve 5'te TGSK şeritler ile güçlendirme uygulanmıştır. Deney elemanlarına uygulanan güçlendirmenin detayları Şekil 3'te verilmiştir. Deney elemanlarına uygulanan güçlendirme detaylarında TGSK şeritler döşemelerin alt yüzeylerine yerleştirilmiş ve boşlukların köşe noktalarına ise döşemelerin üst yüzeyine bağlantı sağlayan ek şeritler yerleştirilerek gerilme yoğunlaşmalarının olduğu bu bölgelerde şeritlerin yüzeyden ayrılmalarına engel olunmaya çalışılmıştır. Ayrıca TGSK şeritlere ek olarak yine karbon malzemeden üretilen ankrajlar şeritlerin üst üste geçiş noktalarında boşlukların köşe noktalarına denk gelecek şekilde yerleştirilmiştir.

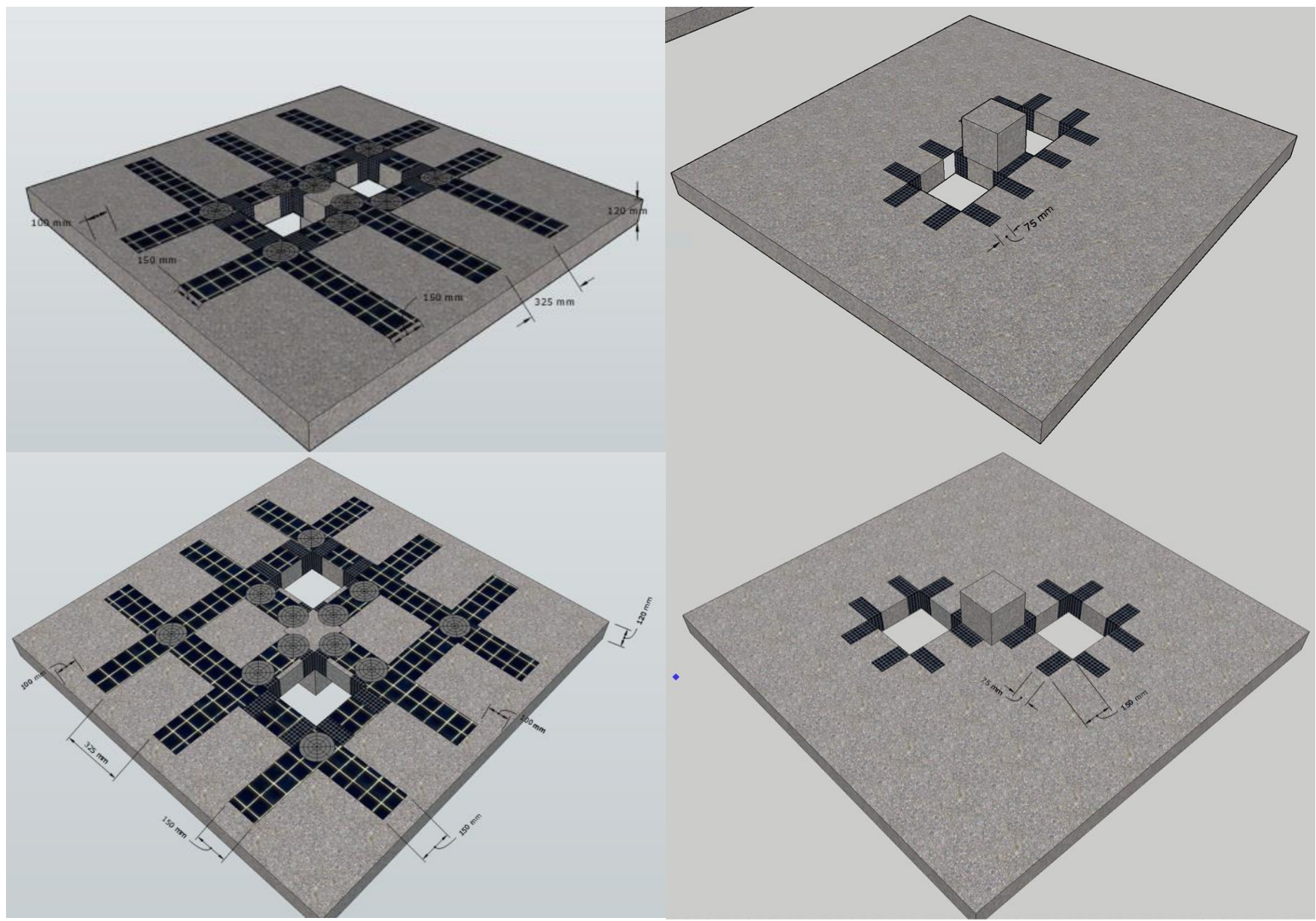

Şekil 3. Deney elemanlarına TGSK şeritler ile uygulanan güçlendirmenin detayları (Tüm ölçüler mm’dir.)

Deney elemanlarının güçlendirilmesinde karbon malzemesi kullanılarak üretilen bir tekstil türü kullanılmıştır. Karbon tekstilin beton yüzeyinden soyulmasını geciktirmek için geleneksel sıva karışımlarının yerine yapısal kalın tamir harcı tercih edilmiştir. Tamir harcının özellikleri üretici firmadan temin edilmiştir. Karışım çimento esaslı ve tek bileşenlidir. Polimer katkısının yanında elyaf katkı da içermektedir. Çalışmada kullanılan malzemelerin özellikleri Tablo 2'de verilmiştir. Bu çalışma kapsamında geliştirilen güçlendirme tekniğinin uygulama adımları sırasında alınan fotoğraflardan seçilen örnekler Şekil 4'de verilmiştir. Şekil 4'de çalışmada kullanılan karbon tekstil malzemesi ve ankrajlar için kullanılan karbon ip malzemeleri görülmektedir. Karbon ipin kök bölümü için epoksi kullanılmış ve ankrajlar epoksi kullanılarak döşemelere açılan deliklere bağlanmıştır. Güçlendirme uygulanmasında ilk olarak karbon tekstilin yerleştirileceği bölümler pürüzlendirilmiş ve ankrajların yerleştirileceği delikler açılmıştır. Daha sonra yüzey ve delikler komprasör ile basınçlı hava kullanılarak temizlenmiş ve nemlendirilmiştir.

Bu aşamadan sonra boyutlarına göre kesilen karbon tekstil şeritler döşeme alt yüzeyine yerleştirildikten sonra karbon ip malzemesi ile hazırlanan ankrajlar konumlarına yerleştirilerek epoksi ile beton yüzeye ve karbon tekstil şeritlere yapıştırılarak ankrajlar tamamlanmıştır. Bir gün süre ile ankrajların epoksilerinin sertleşmesi beklenildikten sonra özel sıva malzemesi karıştırılarak tekstil şeritlerin alt ve üzerine $10 \mathrm{~mm}$ kalınlıkta olacak şekilde sürülerek şeritler sıva ile kapatılmıştır. Güçlendirmesi tamamlanan deney elemanları döşemelere sürülen sıvanın dayanımına ulaşabilmesi için 28 gün kür ortamında bekletildikten sonra test edilmeye hazır hale gelmiştir. Deneylerin gerçekleştirildiği test ve ölçüm düzeneği Şekil 5 'te gösterilmiştir. Deney elemanları mesnet görevi gören çelik profillerin üzerine özel olarak üretilmiş kapalı bir çerçeve içerisine yerleştirilmiştir. Kolona zımbalama yüklemesi olarak uygulanan eksenel yükleme $1000 \mathrm{kN}$ kapasiteli bir hidrolik kriko vasıtasıyla uygulanmış ve bilgisayara bağlı $1000 \mathrm{kN}$ kapasiteli bir yük hücresi ile ölçülmüştür. Eksenel yük, deney elemanlarının merkezinde bulunan kolona rijit bir çelik plaka ile eşit olarak dağıtılmıştır. Yükleme motor kontrollü hidrolik bir yükleme sistemi uygulanmış ve hızı sabit bir yük artış oranı deneylerde özdeş olacak şekilde kullanılmıştır. Deney elemanlarının kolon eksenel deformasyonu ve döşeme deformasyon profillerini belirlemek için Şekil 5'te gösterilen konumlarda 11 adet dikey deformasyon ölçümü alınmıştır. Ölçümler, elektronik deplasman ölçerler (LVDT'ler) ile alınmış ve bilgisayara aktarılmıştır. Alınan ölçümler aracılığı ile deney elemanlarının yük-deplasman ilişkileri, maksimum taşıma kapasiteleri, rijitlikleri ve enerji tüketim kapasiteleri elde edilmiş ve performansları değerlendirilmiştir. 
Tablo 2. Uygulanan güçlendirme yönteminde kullanılan malzemelerin mekanik özellikleri

\begin{tabular}{lc}
\hline $\begin{array}{l}\text { Karbon tekstilin (hasır şeklinde) özellikleri* } \\
\text { Özellikler }\end{array}$ & $255 \mathrm{kN} / \mathrm{m}$ \\
\hline Çekme dayanımı & $350 \mathrm{gr} / \mathrm{m}^{2}$ \\
Ağırlık & $1,43 \mathrm{~mm}$ \\
Kalınlık & $235 \mathrm{MPa}$ \\
Elastisite modülü & $\% 1,7$ \\
Göçme uzaması & $6 \mathrm{~mm}$ \\
\hline Ankraj için kullanılacak karbon ipin özellikleri* & $1,8 \mathrm{gr} / \mathrm{cm}^{3}$ \\
Çap & $>3800 \mathrm{MPa}$ \\
Fiber Yoğunluk & $>230000 \mathrm{MPa}$ \\
Fiber Çekme Mukavemeti & $\% 1,7$ \\
Fiber Elastiklik Modülü & $>7 \mathrm{MPa}$ \\
Fiber Kopmadaki Uzama & $>2 \mathrm{MPa}$ \\
\hline Sıva karışımının özellikleri* & $>60 \mathrm{MPa}$ \\
Eğilme dayanımı & $>20 \mathrm{GPa}$ \\
Beton yüzeye yapışma dayanımı & $1,31 \mathrm{~kg} / \mathrm{lt}$ \\
Basınç dayanımı & Beyaz/Gri bileşen $=4 / 1$ \\
Elastisite modulü & $\mathrm{Min}+10^{\circ} \mathrm{C}$, max $+35^{\circ} \mathrm{C}$ \\
\hline Ankraj yapımında kullanılan epoksinin özellikleri* & $30 \mathrm{MPa}$ \\
Yoğunluk &
\end{tabular}

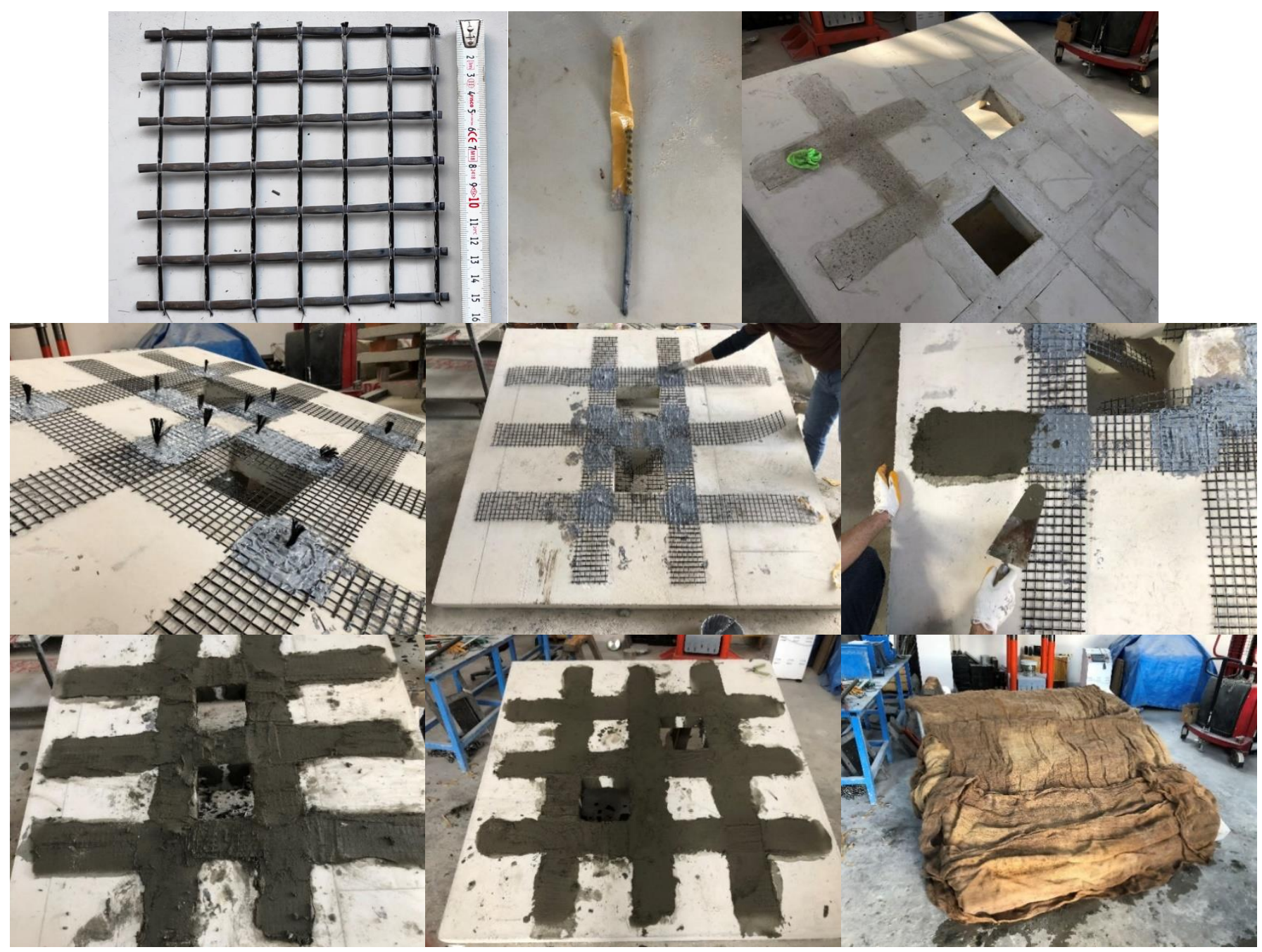

Şekil 4. Deney elemanlarına TGSK şeritler ile uygulanan güçlendirme adımlarından alınan fotograflardan örnekler 


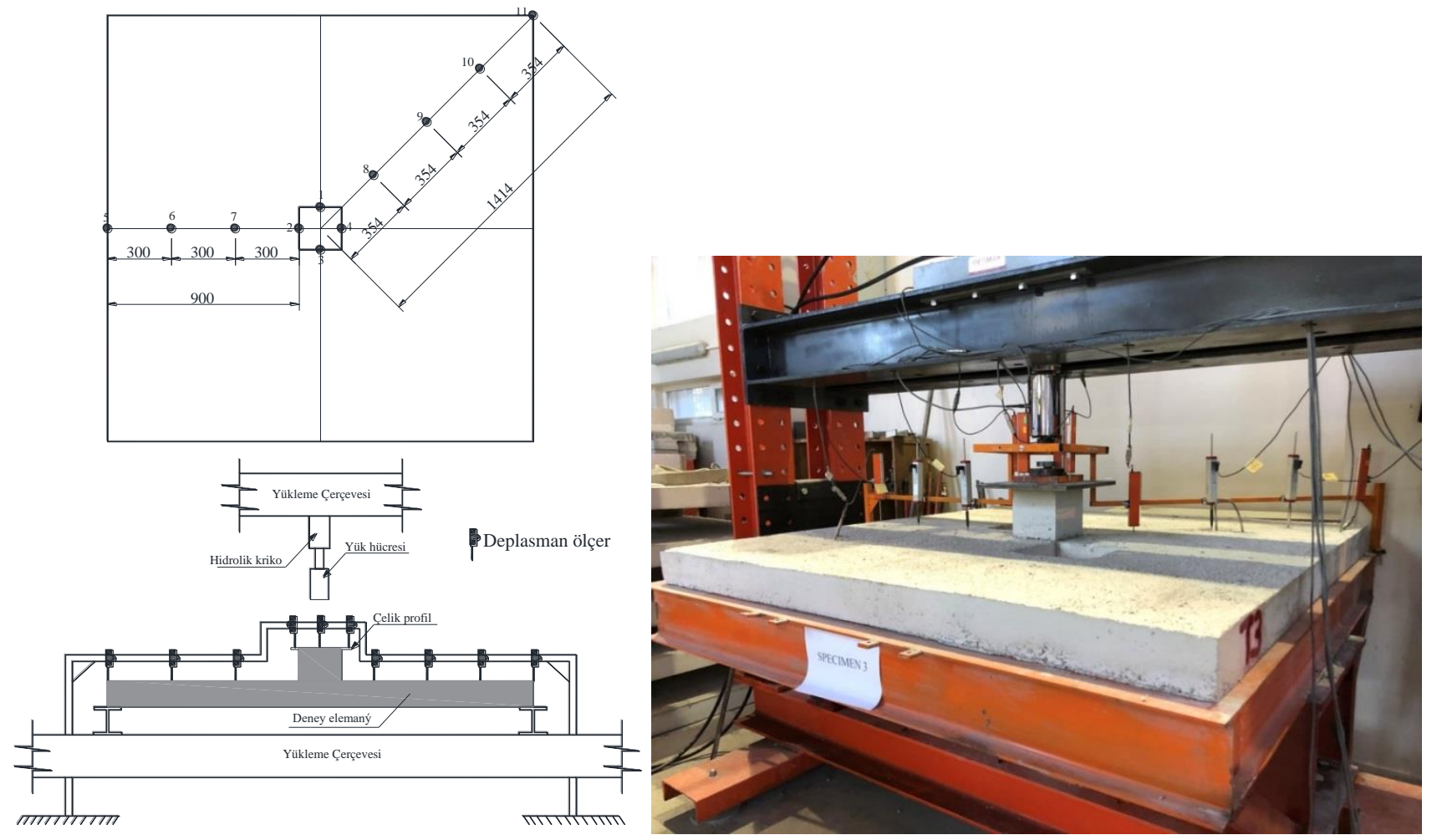

Şekil 5. Deney ve ölçüm düzeneği

\section{Deneysel Sonuçlar ve Yorumlar}

Deneysel çalışma sonucunda çift doğrultulu betonarme döşeme deney elemanları için elde edilen yük-deplasman grafikleri kullanılarak deney elemanlarının maksimum taşıma gücü, başlangıç rijitliği ve enerji tüketim kapasiteleri elde edilmiş ve bu değerler yorumlanarak boşlukların çift doğrultulu betonarme döşemelerin zımbalama yüklemesi etkisi altındaki genel davranışları üzerinde meydana getirdiği olumsuz etkiler ve bu etkilerin azaltılması için çalışma kapsamında önerilen güçlendirme metodunun döşemelerin performansı üzerindeki etkileri incelenmiştir. Deney elemanlarının testlerinden elde edilen sonuçlar Tablo 4'te sunulmuştur. Ayrıca testler sonucunda elde edilen yük-deplasman grafikleri boşluksuz, güçlendirme uygulanmayan referans Deney Elemanı-1 ile karşılaştııılarak Şekil 6'da verilmiştir. Deney elemanlarının performanslarının yorumlanması için kullanılan maksimum taşıma gücü, başlangıç rijitliği ve enerji tüketim kapasitesi değerlerinin hesaplanmasında kullanılan yaklaşımlar ise Şekil 8'de tipik bir yük-deplasman grafiği üzerinde gösterilmiştir.

Tablo 4. Deney Sonuçları

\begin{tabular}{lllll}
\hline $\begin{array}{l}\text { Deney El. } \\
\text { No }\end{array}$ & $\begin{array}{l}\text { Maksimum } \\
\text { Taşıa } \\
\text { Gücü }(\mathrm{kN})\end{array}$ & $\begin{array}{l}\text { Maksimum Taşıma } \\
\text { Gücünde Deplasman } \\
(\mathrm{mm})\end{array}$ & $\begin{array}{l}\text { Başlangıç } \\
\text { Rijitliği } \\
(\mathrm{kN} / \mathrm{mm})\end{array}$ & $\begin{array}{l}\text { Enerji Tüketim } \\
\text { Kapasitesi } \\
(\mathrm{kN}-\mathrm{mm})\end{array}$ \\
\hline 1 & 201,73 & 53,33 & 9,49 & 7684 \\
2 & 110,41 & 27,79 & 5,33 & 1907 \\
3 & 158,61 & 42,99 & 6,59 & 4912 \\
4 & 200,19 & 33,87 & 12,02 & 4742 \\
5 & 225,88 & 52,81 & 13,27 & 8427 \\
\hline
\end{tabular}

Deney elemanlarının testler sonucunda hasar dağılımları ve meydana gelen zımbalama göçme şekillerini gösteren fotoğraflar ise Şekil 7'de verilmiştir. Deney elemanı-1'de boşluk bulunmadığı için klasik bir zımbalama göçmesi gözlemlenmiştir. Öncelikle çekme bölgesinde kolon çevresinde kılcal çatlaklar oluşmaya başlamış ve yük arttıkça bu çatlaklar kolon köşelerinden deney elemanının köşelerine doğru ilerlemiştir. Yük artmaya devam ettikçe çatlaklar kolon ile deney elemanının kenarları arasında kalan bölgenin orta bölgelerinde yoğunlaşarak dallanmaya ve büyümeye başlamıştır. Deney elemanı zımbalama kapasitesine ulaştığında ani bir yük kaybı ile gevrek şekilde göçmüştür. Basınç bölgesinde kolonun oturması gözlemlenmiş ve herhangi bir çatlak oluşmamıştır. Deney elemanı-2'de öncelikle kolon altında küçük kılcal çatlaklar gözlemlenmiştir. Daha sonra boşluklara dik yönde 45 derece açılarla kesme çatlakları oluşmuştur. Kesme çatlakları boşluklara zıt yönde kolona bitişik olarak başlamış ve boşluk kenarının dörtte birlik mesafesinden geçerek kolon ve mesnet arasında kalan bölgenin ortasına doğru ilerlemiştir. Deney elemanının köşe noktalarında yükleme doğrultusuna zıt yönde kalkma gözlemlenmiştir. Çatlaklar bu aşamadan sonra büyümüş ve deney elemanın zımbalama kapasitesi aşılarak gevrek göçme meydana gelmiştir. Deney elemanının basınç bölgesinde önemli bir çatlak gözlemlenmemiştir. Deney eleman1-3'te, deney elemanı-2'ye göre daha büyük bir zımbalama çevresi meydana gelmiştir. Çatlaklar öncelikle çekme bölgesinde kolon çevresinde ve kolon köşesinden döşeme köşelerine doğru kılcal boyutlarda ilerlemiştir. Zımbalama göçmesi sırasında boşlukların dış köşe noktalarının arasında büyük çatlaklar oluşmuştur. Deney elemanının basınç bölgesinde boşluklar arasında çatlaklar oluşmuştur. Deney elemanı 4'te, U şekilli TGSK şeritlerinde kolon kesme çatlakları ve 
kolon deplasmanı önlenirken öte yandan deney elemanının taşıma kapasitesi arttırılmış ve şeritte bulunan tekstil malzemesinde taşıma kapasitesine ulaşılarak kopmalar gözlemlenmiştir. Bu davranış kolon çevresini kuşatan U şekilli TGSK şeritlerinde daha fazla görülmüştür. İşçilik kalitesine bağlı olarak şeritlerin yüzeyden sıyrılarak ayrıldığı tespit edilmiştir. Deney elemanı-5 ise referans deney elemanına göre daha büyük yük kaybı ile gevrek bir şekilde zımbalama etkisine maruz kalmıştır.
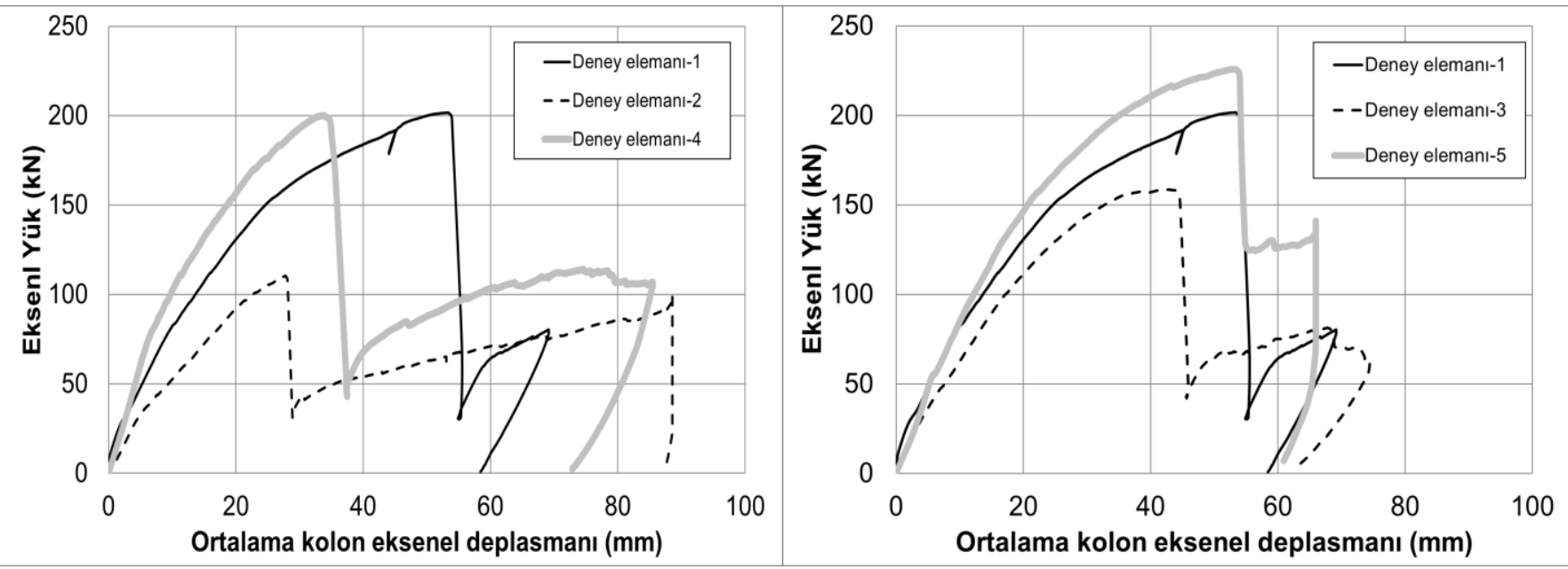

Şekil 6. Deney elemanlarının yük-deplasman grafikleri
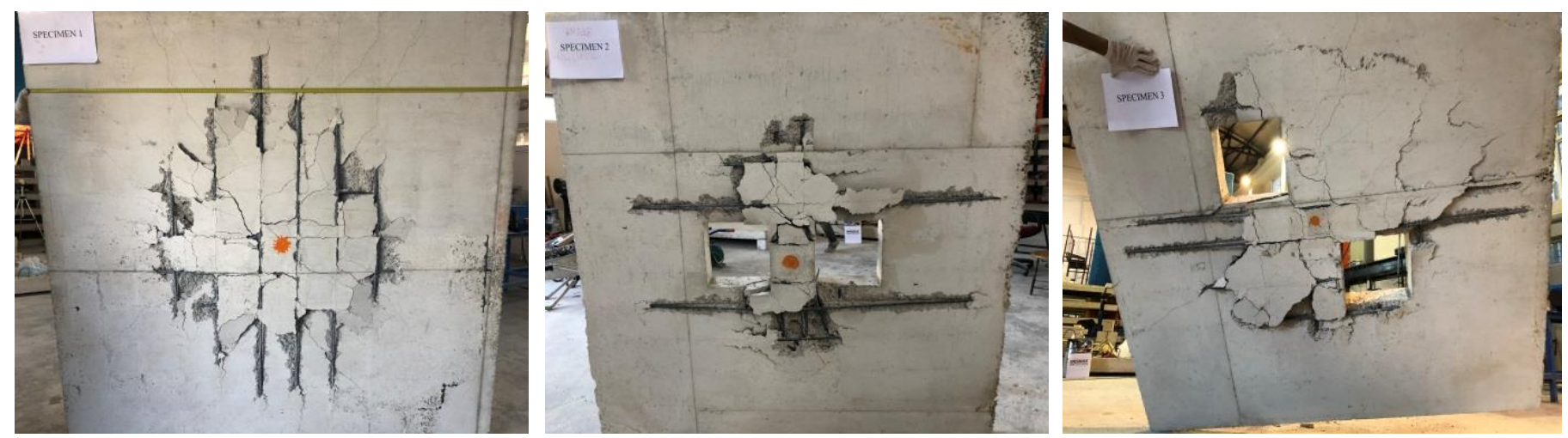

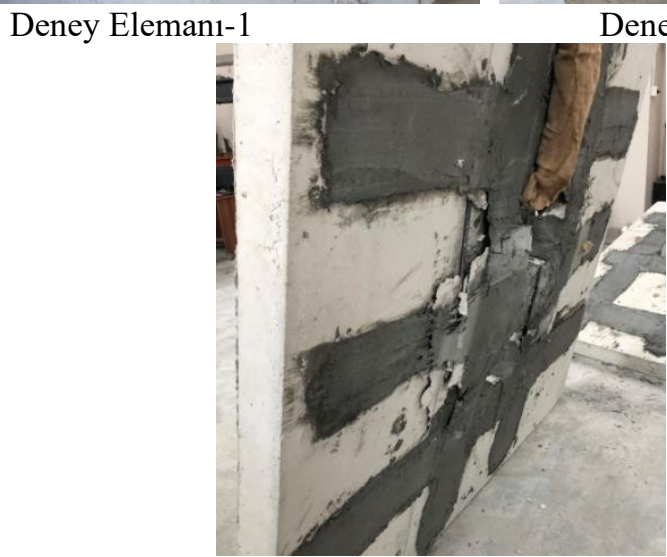

Deney Elemanı-4

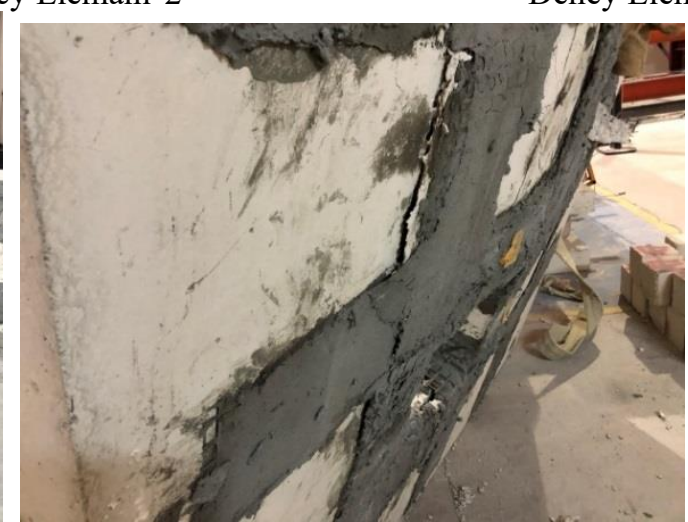

Deney Eleman1-5

Şekil 7. Deney elemanlarının hasar dağılımları

Deneysel çalışma kapsamında güçlendirilmeden test edilen boşluksuz Deney Elemanı-1 ve 300×300 mm boyutlarında iki adet boşluğa sahip Deney Elemanı 2 ve 3'ün sonuçları incelendiğinde çift doğrultulu betonarme döşemelerde bırakılan boşlukların genel yük-deplasman davranışını ve zımbalama performansını son derece olumsuz etkilediği görülmüştür. Deney elemanlarında yer alan boşluklar döşemelerin maksimum taşıma gücü kapasitesi, başlangıç rijitliği ve enerji tüketim kapasitesi değerlerinin boşluksuz referans Deney Elemanı-1'e göre sirasıyla ortalama \%33, \%37 ve \%56 oranlarında azalmasına neden olmuştur. Deney elemanlarında yer alan boşlukların konumları da döşemelerin zımbalama yüklemesi etkisi altındaki performans düzeyleri ve genel yük deplasman davranışları üzerinde etkili olan bir parametredir. $300 \times 300 \mathrm{~mm}$ boyutlarında iki adet boşluğu kolona paralel olarak alt ve üstte konumlandırılan Deney Elemanı-2'nin maksimum taşıma gücü, başlangıç rijitliği ve enerji tüketim kapasitesi değerleri, boşluksuz Deney Elemanı-1 referans deney elemanından sırasıyla \%45, \%44 ve \%75 oranlarında azalmıştır. $300 \times 300$ mm boyutlarındaki boşlukların konumları değişim gösterip kolona göre köşe noktalarına diyagonal olacak şekilde konumlandığı Deney Elemanı 3'ün zımbalama yüklemesi etkisi altındaki davranışı Deney Elemanı-2'ye göre bir miktar daha iyi olmasına rağmen yine 
de maksimum taşıma gücü, başlangıç rijitliği ve enerji tüketim kapasitesi değerleri, boşluksuz Deney Elemanı-1 referans deney elemanına göre $\% 27, \% 31$ ve \%36 oranlarında azalmıştır. Elde edilen bu sonuçlar döşemelerde bırakılan boşlukların zımbalama yüklemesi etkisi altındaki davranışı çok büyük ölçüde olumsuz etkilediğini, döşemelerin maksimum taşıma gücü, başlangıç rijitliği ve enerji tüketim kapasitesi gibi önemli parametrelerinin hepsinin birden azalmasına neden olduğunu göstermiştir.

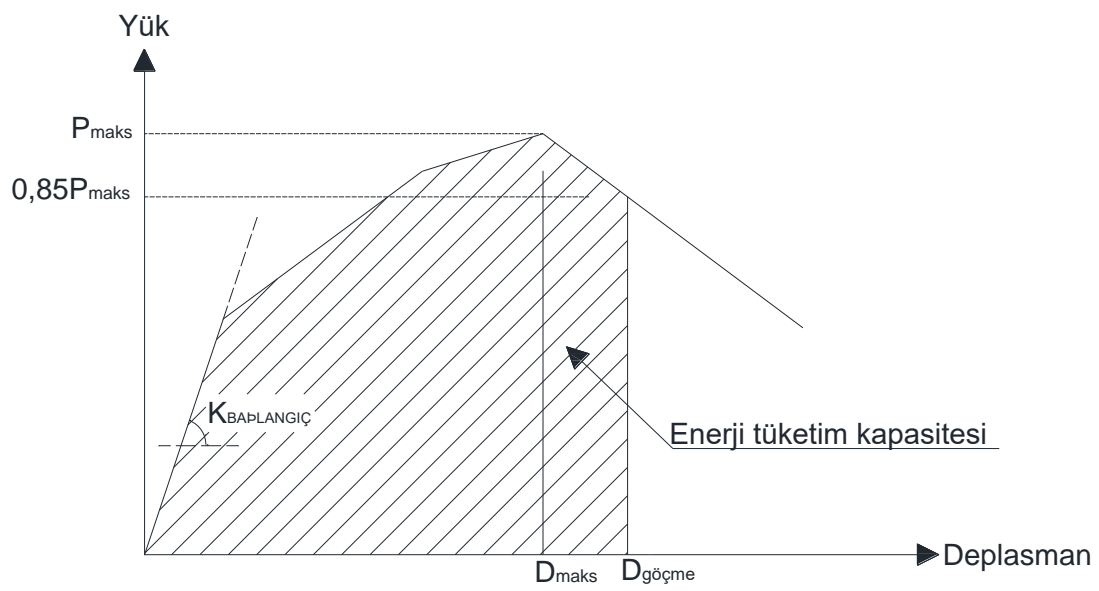

Şekil 8. Deney elemanlarının başlangıç rijitliği ve enerji tüketim kapasitelerinin hesaplanmasında kullanılan yaklaşım

Çalışma kapsamında boşlukların döşemelerin zımbalama yüklemesi etkisi altındaki davranışı üzerinde meydana getirdiği olumsuz etkileri azaltmak için geliştirilen güçlendirme metodu uygulanarak test edilen Deney elemanı 4 ve 5 'ten elde edilen sonuçlar incelendiğinde önerilen güçlendirme metodunun maksimum taşıma gücü ve başlangıç rijitliği değerlerinin iyileştirilmesinde son derece etkili olduğu ve bu değerleri önemli oranlarda artırdığı görülmüştür. Geliştirilen güçlendirme metodunun boşluklu döşemelerin maksimum taşıma güçleri ve başlangıç rijitliği değerleri üzerinde meydana getirdiği iyileştirme son derece yüksek oranda olmuş, birden fazla boşluklu döşemelerin performans düzeylerini boşluksuz referans Deney Elemanı-1 düzeyine çıkartmayı başarmıştır. Uygulanan güçlendirme metodu boşluklu döşemelerin enerji tüketim kapasitesinin artırılmasında da etkili olmuş güçlendirme uygulanmayan boşluklu deney elemanlarına göre önemli oranda bir artış meydana getirmiş ve Deney Elemanı 5 'te enerji tüketim kapasitesi boşluksuz Deney Elemanı-1 referans deney elemanı enerji tüketim kapasitesi değerini aşmıştır. Tekstil takviyeli şeritler ile güçlendirilen $300 \times 300 \mathrm{~mm}$ boyutlarında iki adet boşluğu kolona paralel olarak alt ve üstte konumlandırılan Deney Elemanı-4'ün maksimum taşıma gücü değeri boşluksuz Deney Elemanı-1 referans deney elemanı ile eşit sayılabilecek düzeye ulaşmış, başlangıç rijitliği değeri \%27 daha fazla elde edilmiş ve enerji tüketim kapasitesi değeri ise \%38 oranında azalmıştır. Tekstil takviyeli şeritler ile güçlendirilen $300 \times 300 \mathrm{~mm}$ boyutlarında iki adet boşluğu kolonun köşelerinde diyagonal konumda yer alan Deney Elemanı-5'in maksimum taşıma gücü, başlangıç rijitliği ve enerji tüketim kapasitesi değerleri boşluksuz Deney Elemanı-1 referans deney elemanından sırasıla \%12, \%40 ve \%10 oranlarında daha fazla elde edilmiştir. Uygulanan güçlendirme metodu Deney Elemanı-5 üzerinde son derece etkili olmuş ve geliştirilen yöntem ile güçlendirilen döşeme boşluksuz Deney Eleman1-1'in maksimum taşıma gücü, başlangıç rijitliği ve enerji tüketim kapasitesi değerlerinin tümünde geçerek son derece yüksek bir performans sergilemiş ve başarılı olmuştur.

Deney elemanlarında meydana gelen zımbalama göçmesi sonrasında yükleme işlemine devam edilmiştir. Bu işlem sonucunda Şekil 6' da verilen yük deplasman grafikleri incelendiğinde yük için ikinci bir tepe noktası oluştuğu görülmüştür. Bunun nedeni zımbalama sonrasında oluşan yeniden dağılım ile deney elemanlarının bir kiriş gibi eğilme kuvvetlerine karşı çalışmaya başlamasından kaynaklandığı düşünülmüştür.

\section{Sonuçlar}

Bu çalışma kapsamında birden fazla boşluğun çift doğrultulu betonarme döşemelerin zımbalama yüklemesi etkisi altındaki genel yük deplasman davranışları ve performansları üzerinde meydana getirdiği olumsuz etkilerin incelenmesi ve söz konusu olumsuz etkilerin azaltılması için güçlendirme uygulamalarında yeni yeni kullanılmaya başlanan TGSK şeritler ile geliştirilen yeni bir güçlendirme metodunun etkinlik düzeyinin yorumlanması amaçlanmıştır. Bu amaçla çalışmada 5 adet deney elemanı üretilmiş ve 2 deney elemanı geliştirilen güçlendirme metodu ile güçlendirilerek, güçlendirme uygulanmayan deney elemanları ile karşılaştırılarak metodun performans üzerindeki etkileri araştırılmıştır. Çalışmada incelenen değişken betonarme döşemelerde bırakılan boşlukların konumudur. Kolona paralel olarak alt ve üste bitişik olarak bırakılan iki adet boşluğun döşemelerin zımbalama davranışını, maksimum taşıma gücü, başlangıç rijitliği ve enerji tüketim kapasitesi değerlerini boşlukların kolona göre diyagonal şekilde köşe noktalar ile bitişik şekilde konumlandırıldığı duruma göre daha fazla olumsuz etkilediği görülmüştür. Uygulanan güçlendirme metodu boşlukların her iki konumda da yer alması durumunda döşemelerin maksimum taşıma gücü, başlangıç rijitliği ve enerji tüketim kapasitesi değerlerini önemli oranlarda artırmış ve zımbalama yüklemesi etkisi altındaki genel yük-deplasman davranışında etkili bir performans artışı sağlamıştır. Özellikle boşlukların diyagonal şekilde konumlandırıldığı Deney Elemanı-5'te geliştirilen güçlendirme metodu son derece etkili olmuş maksimum taşıma gücü, başlangıç rijitliği ve enerji tüketim kapasitesi değerlerinin tümü boşluksuz referans Deney Elemanı-1'in değerlerinin üzerine geçerek beklenilenin ötesinde bir performans artış1 sağlanmıştır. 


\section{Teșekkür}

Bu çalışma, “119M985” proje numarası ve "Boşluk Yeri ve Büyüklüğü Değişen Çift Doğrultulu Betonarme Döşemelerin Tekstil ile Güçlendirilmiş Sıva ve Karbon Takviyeli Elyaf Kumaşlar ile Zımbalamaya Karşı Güçlendirilmesi” proje başlığı ile TÜBíTAK1001-Bilimsel ve Teknolojik Araştırma Projelerini Destekleme Programı tarafından finanse edilmiştir.

\section{Referanslar}

Aksoylu, C., Yazman, Ş., Özkılıç, Y. O., Gemi, L., \& Arslan, M. H. (2020). Experimental analysis of reinforced concrete shear deficient beams with circular web openings strengthened by CFRP composite. Composite Structures, 249, 112561.

Gemi, L., Aksoylu, C., Yazman, Ş., Özkılıç, Y. O., \& Arslan, M. H. (2019). Experimental investigation of shear capacity and damage analysis of thinned end prefabricated concrete purlins strengthened by CFRP composite. Composite Structures, 229, 111399.

Gemi, L, Madenci, E, Özkılıç, Y. (2020). Çelik, Cam FRP ve Hibrit Donatılı Betonarme Kirişlerin Eğilme Performansının İncelenmesi. Düzce Üniversitesi Bilim ve Teknoloji Dergisi, 8 (2) , 1470-1483 . DOI: 10.29130/dubited.629354.

Giovanni, L., Lorenzo, L., Diana, A., Antonio, N. 2014. "Performance of RC Slab-Type Elements Strengthened with FabricReinforced Cementitious-Matrix Composites”, ASCE Journal of Composites for Construction, 18(3), 1-9.

İşleyen, Ü. K., Ghoroubi, R., Mercimek, Ö., Anil, Ö., and Erdem, R. T. (2021). Behavior of glulam timber beam strengthened with carbon fiber reinforced polymer strip for flexural loading. Journal of Reinforced Plastics and Composites, 0731684421997924.

Jesse, F., Weiland, S., and Curbach, M. 2008. "Flexural strengthening of RC structures with textile-reinforced concrete", ACI Special Publication, 250, 49-58.

Jung, K. S. H., Hong, S. H., Ko, K. N., Cho, W. J., Yong-In. 2016. “An Experimental Study on the Flexural Capacity of RC Slab Strengthened with Textile Reinforced Mortar (TRM)", Journal of the Korean Society for Advanced Composite Structures, 7(4), 110 .

Koutas L. N., Bournas, D. A. 2017. "Flexural Strengthening of Two-Way RC Slabs with Textile-Reinforced Mortar: Experimental Investigation and Design Equations", ASCE Journal of Composites for Construction, 21(1), 4016065, 1-11.

Mercimek, Ö., Ghoroubi, R., Anil, Ö., Çakmak, C., Özdemir, A., and Kopraman, Y. (2020). Strength, ductility, and energy dissipation capacity of RC column strengthened with CFRP strip under axial load. Mechanics Based Design of Structures and Machines, 1-19.

Mercimek, Ö., Ghoroubi, R., Baran, M., and Anil, Ö. (2021). Behaviour of steel beams retrofitted with anchored carbon-fibrereinforced polymer strip. Proceedings of the Institution of Civil Engineers-Structures and Buildings, 1-32.

Özkılıç, Y. O., Yazman, Ş., Aksoylu, C., Arslan, M. H., \& Gemi, L. (2021). Numerical investigation of the parameters influencing the behavior of dapped end prefabricated concrete purlins with and without CFRP strengthening. Construction and Building Materials, 275, 122173 .

Papanicolaou, C., Triantafillou, T., Papantoniou, I., Balioukos, C. 2009. "Strengthening of two-way reinforced concrete slabs with textile reinforced mortars (TRM)", Proc., 4th Colloquium on Textile Reinforced Structures (CTRS4), M. Curbach and F. Jesse, eds., Dresden, Germany, 409-420.

Ghoroubi, R., Mercimek, Ö., Özdemir, A., and Anil, Ö. (2020, December). Experimental investigation of damaged square short RC columns with low slenderness retrofitted by CFRP strips under axial load. In Structures (Vol. 28, pp. 170-180). Elsevier.

Ghoroub1, R., Mercimek, Ö., Sakın, S., and Anıl, Ö. (2021). Novel bond-slip model between concrete and angular CFRP fan type anchoraged CFRP strip. European Journal of Environmental and Civil Engineering, 1-19.

Schladitz, F., Frenzel, M., Ehlig, D., Curbach, M. 2012. "Bending load capacity of reinforced concrete slabs strengthened with textile reinforced concrete", Engineering Structures, 40, 317-326.

Zwicky D. 2013. "Concrete Slab Strengthening with CFRP Textile Reinforced Shotcrete”, IABSE Symposium Rotterdam. 